\title{
The effects of $\mathbf{N}, \mathbf{P}$ and crude oil on the decomposition of Spartina alterniflora belowground biomass
}

\author{
R. Eugene Turner · James E. Bodker
}

Received: 8 May 2015/Accepted: 24 August 2015/Published online: 29 August 2015

(C) The Author(s) 2015. This article is published with open access at Springerlink.com

\begin{abstract}
We conducted a laboratory experiment to examine how the decomposition of particulate belowground organic matter from a salt marsh is enhanced, or not, by different mixtures of crude oil, nitrogen $(\mathrm{N})$, or phosphorus (P) acting individually or synergistically. The experiment was conducted in $3.8 \mathrm{~L}$ sampling chambers producing varying quantities of gas whose volume was used as a surrogate measure of organic decomposition under anaerobic conditions. Gas production after 28 days, from highest to lowest, was $+\mathrm{NP}=+\mathrm{N}>>>+\mathrm{P}$, or + oil. The gas production under either $+\mathrm{P}$ or + oil conditions was indistinguishable from gas production in the control chamber. Nitrogen, not phosphorus, or $+\mathrm{NP}$, was the dominant factor controlling organic decomposition rates in these experiments. The implication for organic salt marsh soils is that shoreline erosion is enhanced by salt marsh oiling, presumably by its toxicity, but not by its effect on the decomposition rates of plant biomass belowground. Nutrient additions, on the other hand, may compromise the soil strength, creating a stronger disparity in soil strength between upper and lower soil layers leading to marsh loss. Nutrient amendments intended to decrease oil concentration in the marsh may not have the desired effect, and are likely to
\end{abstract}

R. E. Turner $(\bowtie) \cdot$ J. E. Bodker

Department of Oceanography and Coastal Sciences, Louisiana State University, Baton Rouge, LA 70803, USA

e-mail: euturne@1su.edu decrease soil strength, thereby enhancing marsh-towater conversions in organic salt marsh soils.

Keywords Salt marsh · Decomposition . Belowground biomass $\cdot$ Nitrogen $\cdot$ Phosphorus · Oil

\section{Introduction}

The strength of salt marsh soils may be comprised by increased exposure to crude oil (Hampson 2000; McClenachan et al. 2013), nutrient loading (Turner et al. 2009, 2011; Deegan et al. 2012; Wigand et al. 2014), and from other influences, including the anticipated consequences of the global climate change (Watson et al. 2014). The strength of these present and future threats is influenced by several factors, including how they influence the quantity of root and rhizome biomass holding soil together (like reenforced metal rods in concrete), and change the decomposition of particulate organics that accumulated over centuries maintaining an equilibrium with sea level rise (Turner et al. 2000).

The results from field experiments have documented that nutrient enrichment of salt marshes may change both the standing stock and the turnover of belowground organics, but not to the same degree in all salt marshes. The field-based experimental results from salt marshes dominated by organic soils documented reduced root biomass in $\mathrm{P}$ amended Spartina alterniflora marshes (S. alterniflora is the dominant 
macrophyte), but not with $\mathrm{N}$ additions (Darby and Turner 2008a, b). Valiela et al. (1976) observed similar reductions of the biomass of live roots + rhizomes for sewage-amended salt marshes in Massachusetts (USA). In contrast to these results for peaty soils, Wigand et al. (2015) reported that minerogenic salt marshes in South Carolina (USA) had higher standing stocks of roots and rhizomes (but not fine roots) in the $0-20 \mathrm{~cm}$ layer within experimental plots of mineral soils amended with $\mathrm{N}$ and $\mathrm{P}$.

One indicator of the effects of nutrient enrichment on salt marshes is carbon turnover, which is a significant issue when trying to constrain or balance the global $\mathrm{C}$ budget. Salt marshes amended with $\mathrm{N}$ or with $\mathrm{N}$ and $\mathrm{P}$ have enhanced respiration rates compared to reference marshes (Morris and Bradley 1999; Wigand et al. 2015), but not with $P$ amendments (Anisfeld and Hill 2012; Wigand et al. 2015). Wigand et al. (2009), however, documented a direct relationship between soil respiration and $\mathrm{N}$ loading in Narragansett Bay salt marshes.

The cumulative effect of changes in the organic amounts, form, and decomposition rate on soil strength may eventually cause wetland conversion to open water through reductions in soil strength. Experimental nutrient additions to organic-rich salt marsh soils in New England and Louisiana (USA) documented soil strength losses $50 \mathrm{~cm}$ deep (Turner et al. 2009, 2011), which is below where most live roots and rhizomes are found. Deegan et al. (2012) increased the nitrate and phosphate concentration entering replicated salt marshes in Massachusetts and documented higher slumping of tidal creeks and horizontal shearing of the top $50 \mathrm{~cm}$ of marsh. Kearney et al. (2011) attributed the loss of one-third of the coastal wetlands $\left(-142 \mathrm{~km}^{2}\right)$ in an estuarine sub-watershed to the weakening of marsh soils when the area was exposed to nutrient-enriched Mississippi River water diverted into the area. These observations are consistent with Swarzenski et al.'s (2008) comparative analysis of ogliotrophic marshes receiving nutrient-rich Mississippi River water.

Most of these studies added $\mathrm{N}$ and $\mathrm{P}$ together, but not separately. The $\mathrm{N}$ load in the Narragansett Bay marshes and elsewhere mentioned above, for example, is a consequence of cultural eutrophication and is accompanied by an unmeasured increase in the $\mathrm{P}$ loading. Debusk and Reddy (2005) and Qualls and Richardson (2008) found that carbon loss in experimental Everglades peat sites was directly related to phosphate concentration in the water flowing through them. So it is possible that either $\mathrm{N}$ or $\mathrm{P}$ or both acting together will have distinctive or overlapping influences that are dependent on soil or plant quality. We cannot, therefore, easily or quickly isolate the effects of added $\mathrm{N}$ from the effects of added $\mathrm{P}$, or from the synergistic impacts in regional field studies.

Nutrient enrichment is not, of course, the only stressor diminishing salt marsh stability. There are multiple potential chronic stressors, including those arising from alterations in the hydrologic regime, sea level rise, and the top-down effects of food web alterations (e.g., Silliman et al. 2009). A dramatic recent exposure to stress was from the $2010 \mathrm{BP}$ Macondo oil disaster (aka Deepwater Horizon; DWH) in the Gulf of Mexico, which resulted in $1773 \mathrm{~km}$ of shoreline oiling, decreases in soil strength below $50 \mathrm{~cm}$, and increased shoreline erosion (Michel et al. 2013; McClenachan et al. 2013). There were shoreline marshes that subsided in situ soon after the spill, and others that eroded at the edge (Fig. 1). Greenhouse studies have revealed an inverse dose-response relationship between fuel oil and the aboveground growth of $S$. alterniflora, with a $50 \%$ reduction in belowground biomass (Lin et al. 2002). Although we know that the soil was weakened by the exposure to oil, we don't know if this effect results only from the oil's toxicity on the plants, or if it was also from the stimulatory effect on decomposition rate, or some combination of both.

The potential effects of nutrient enrichment and oiling on salt marshes have, therefore, comparable qualitative outcomes belowground. If nutrients are applied post-spill in an effort to mitigate oil residency and impacts, as sometimes recommended (e.g., Venosa et al. 2002), then the effects of oil and nutrients on marsh stability might become a synergistically stronger or weaker agent of change. Some key information is required, therefore, to separate out the effects of $\mathrm{N}, \mathrm{P}$ and oil on marsh stability.

Here we report the results from an experiment comparing the effects of nutrient enrichment and crude oil on the decomposition of salt marsh belowground biomass. The experiment was developed to address four questions: (1) does $\mathrm{N}$ or $\mathrm{P}$ control the decomposition rate of the belowground biomass? (2) does the presence of oil change the organic matter 

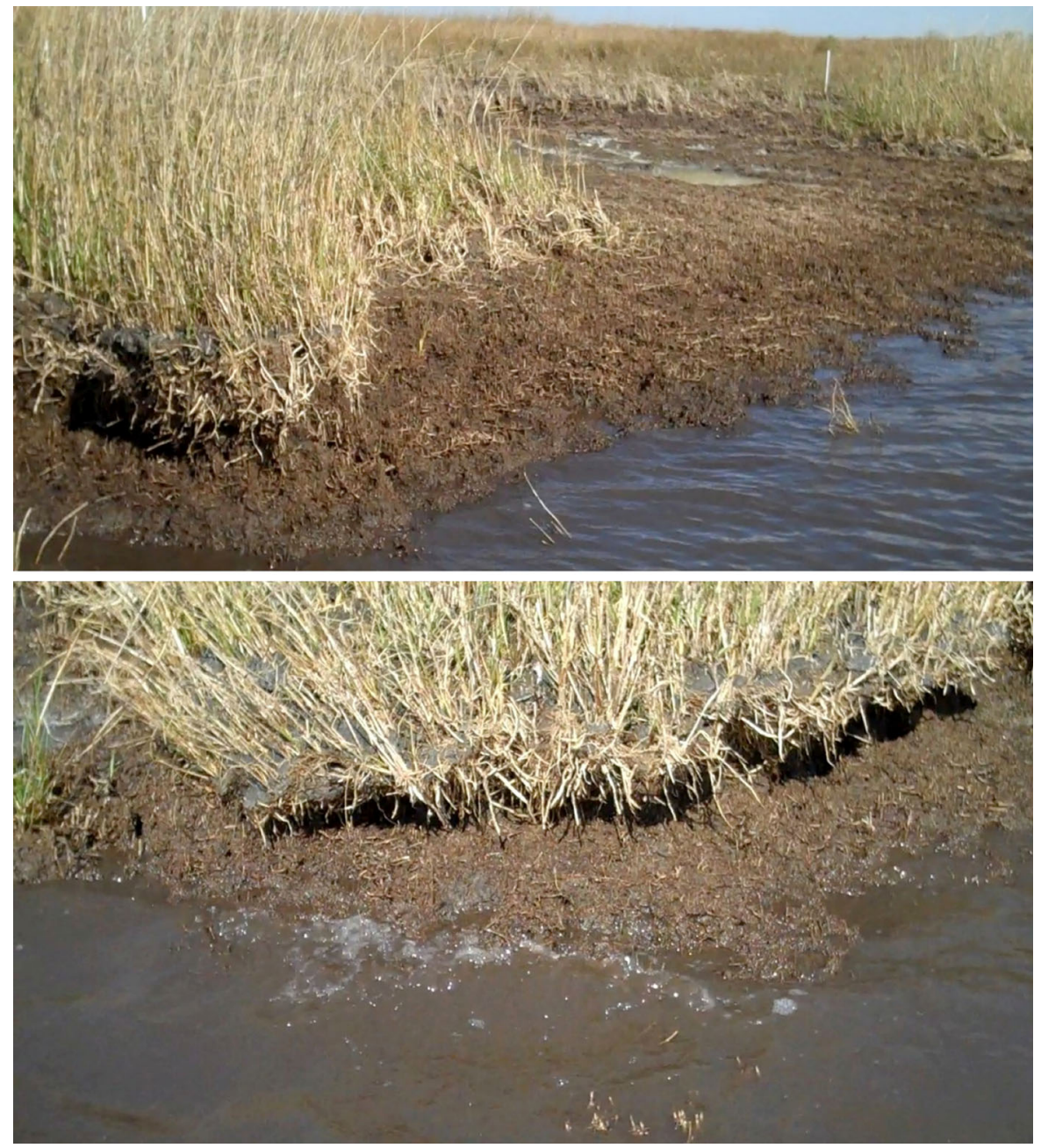

Fig. 1 Oiled salt marshes in eastern Barataria Bay, LA (USA). The top photo shows a crenulated shoreline formed after a large section subsided. The bottom photo is of a shoreline that eroded below the rooting depth creating an undercut (notice the

decomposition rate? (3) is there synergism between oil and nutrients on the decomposition rate?, and, (4) will nutrient addition change the oil decomposition rate?

\section{Methods}

We conducted laboratory experiments on the decomposition of $S$. alterniflora belowground biomass. Belowground biomass was incubated for 26 days in artificial seawater together with additions of various triplicated combinations of N, P and crude oil. The gas volume generated was used as a relative index of the shadow) at the creek bank. The broken stems punctuating the water's surface in photo's foreground are anchored in the former marsh surface. The photos were taken February 2011 by RET

various experimental additions on the decomposition rate.

Belowground biomass

We collected belowground biomass from a salt marsh in Barataria Bay, LA, in spring 2010 using a $40 \mathrm{~cm}$ long stainless steel tube with a sharpened edge. The sediment core was extruded in the lab where it was cut into $10 \mathrm{~cm}$ sections. The sections between 10 and $30 \mathrm{~cm}$ deep were washed over a $2 \mathrm{~mm}$ sieve lying above a $0.5 \mathrm{~mm}$ sieve. Fine root material was thereby captured passing through the $2 \mathrm{~mm}$ sieve. Live roots 
and rhizomes were not separated from dead material which was in various stages of decomposition. The resulting pool of belowground biomass used in the experiments is mostly dead, not live, belowground biomass which forms $98 \%$ of the organics in the soil profile of Louisiana salt marshes (Darby and Turner $2008 \mathrm{a}, \mathrm{b})$. The sedimentation rate of marshes in Barataria Bay is between 0.52 and $0.8 \mathrm{~cm} /$ year $^{-1}$ (Milan et al. 1995), implying that the oldest organic material included in these experiments is in the range of 37-57 years old.

The belowground material was dried to a constant weight at $60{ }^{\circ} \mathrm{C}$ and subsamples weighed to the nearest $0.01 \mathrm{~g}$. Dried root material was ground in a grinder and sent to the Louisiana State University, Soil Testing and Plant Analysis Lab where it was analyzed to determine the total $\mathrm{C}, \mathrm{N}$ and $\mathrm{P}$ content. The total $\mathrm{C}$ and $\mathrm{N}$ content was determined by combustion (Leco CHN analyzer). The total $\mathrm{P}$ was determined after digestion with nitric acid $\left(\mathrm{HNO}_{3}\right)$ and hydrogen peroxide (H2O2) using a Spectro Arcos model FHE12 inductively coupled plasma spectrophotometer (manufactured 2008). The nutrient concentrations units of the biomass are expressed as the \% mass of the dry weight.

Incubation chamber

Thirty-three $\mathrm{g}$ of dried belowground biomass was placed in a $3.8 \mathrm{~L}$ incubation chamber (Fig. 2) and various combinations of $\mathrm{N}, \mathrm{P}$ and/or oil added. Each treatment was done in triplicate. Gas production generated within the incubation chamber displaced water up the vertical tube embedded in the substrate. Gas production was assumed to be equal to the water volume displaced. A relief valve was periodically opened to drain the water in the tube and replacement water was added. Gas was extracted from a side-wall port. The incubation chamber was covered with aluminum foil to reduce light exposure. The incubation temperature was between 22 and $25^{\circ} \mathrm{C}$.

Initial water quality

All incubation chambers included the $33.0 \mathrm{~g}$ of belowground biomass and artificial seawater (33 ppt salinity) supplemented with various amounts of nitrate, phosphate and oil. The treatments were: (1) no addition (control), (2) +oil, (3) phosphorus $(+\mathrm{P})$,

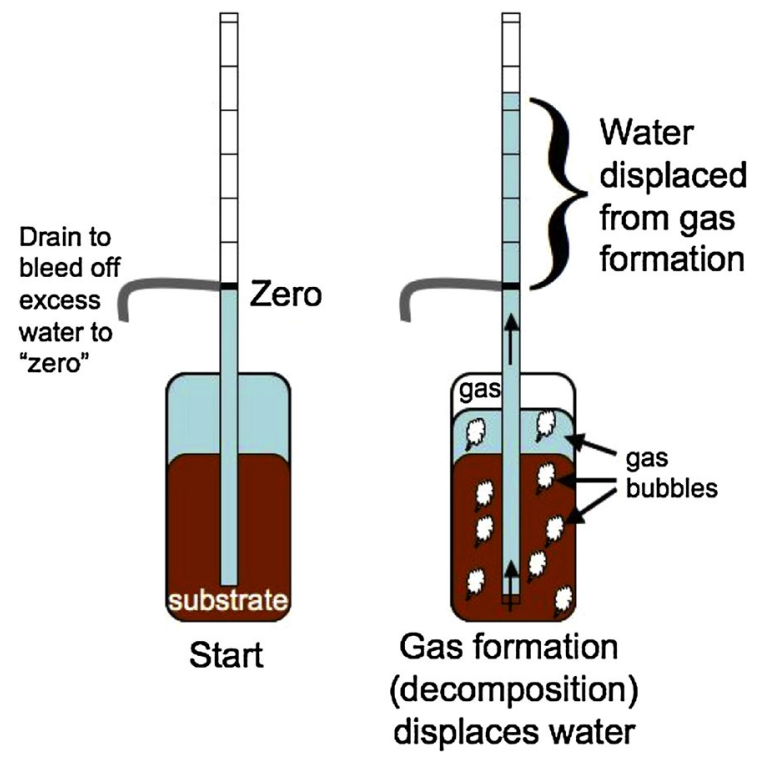

Fig. 2 The experimental setup

(4) nitrogen $(+\mathrm{N})$, (5) nitrogen and phosphorus $(+\mathrm{NP})$, and (6) oil and $+\mathrm{NP}(+$ oil $+\mathrm{NP})$. The oil addition consisted of $5 \mathrm{ml}$ of south Louisiana crude oil added to each chamber. The $+\mathrm{N}$ and $+\mathrm{P}$ treatment was achieved with an addition of inorganic nitrate (as potassium nitrate) or phosphate (as potassium phosphate) sufficient to raise the concentration in the chamber to 357 and $22.3 \mu \mathrm{M}$ nitrate or phosphate, respectively, equivalent to a $\mathrm{N}: \mathrm{P}$ atomic ratio of $16: 1$. These concentrations are about the same dissolved inorganic concentrations of nitrogen and phosphate for porewater in a Rhode Island marsh experiment (Caffrey et al. 2007) and are similar to the nitrogen concentration for some urbanized estuarine systems (e.g., Benotti et al. 2007). The concentrations at the beginning of the experiment were higher than those achieved in Deegan et al.'s (2007) whole marsh enrichment experiment. Deegan et al. (2007) maintained the nitrate and phosphate concentration in creeks during the growing season at 70 and $4 \mu \mathrm{M}$ nitrate and phosphate, respectively (Deegan et al. 2007).

The oil concentration of alkane and aromatics per mass of sediment ( $33 \mathrm{~g}$ ) was 123 and $25,110 \mathrm{mg} \mathrm{kg}^{-1}$, respectively, in the control chambers at the beginning of the experiment. These concentrations are similar to the average alkane and aromatic concentration in the top $5 \mathrm{~cm}$ of marshes oiled in the 2010 Macondo oil 
'spill', which was 991 and 29,997 $\mathrm{mg} \mathrm{kg}^{-1}$, respectively (Turner et al. 2014).

\section{Oil analyses}

The sample analysis details are described in greater detail in Turner et al. (2014). The analysis identified 28 alkanes and 43 aromatic hydrocarbons and their respective alkyl homologs using GC/MS-SIM (gas chromatography/mass spectrometry in selective ion monitoring mode), including the normal and branched saturated hydrocarbons (from C10 to C35), the one- to five-ringed aromatic hydrocarbons and their $\mathrm{C} 1-\mathrm{C} 4$ alkyl homologs, as well as cyclic biomarker compounds like the hopanes, steranes and triaromatic steroids (SIM ions 191, 217, 218, and 231 eluting between $\mathrm{C}_{23}$ and $\mathrm{C}_{31}$ ).

The water samples were analyzed using accepted standard operating and QA/QC procedures to prevent contamination and avoid sample degradation. These are described in detail in Turner et al. (2014), and briefly here. The samples were extracted with dichloromethane (DCM) and spiked with surrogate standards to achieve a final extract concentration of $20 \mu \mathrm{g} \mathrm{mL}^{-1}$. The concentrations of the target aromatics (PAHs) were determined by an internal standard method and response factor calculated from a 5-point calibration curve using a commercially-available standard containing the normal alkanes from n-C10 through n-C35 and the parent PAH analytes of interest. The MS detector was tuned to PFTBA (perfluorotributylamine) before each set of analyses. If any of the tune parameters (e.g., percent air/water, peak abundances and ratios) were significantly different from before tune parameter values, then the instrument was checked for errors and then returned to normal operating conditions.

A daily calibration standard and blank were analyzed with each sample batch to verify proper instrument performance. If the daily standard indicated instrumental problems, then no further analytical work was performed until the instrument was restored to good operating condition. The identities of all analytes were established using retention times and full scanning mass spectral data. The spectral data were processed by Chemstation Software (Agilent Technologies). Only the total alkane and total aromatic concentrations are included herein. The data are archived at (http://dx.doi.org/10.7266/N78050JZ).
Statistical analyses

The data are presented as means \pm 1 standard error $( \pm 1 \mathrm{SE} ; \mathrm{n}=3)$. The cumulative mean gas volumes $(\mathrm{mL})$ released over the entire 28 days were analyzed with a Tukey-Kramer test, which includes the extension by Kramer to allow for unequal sample sizes. It was used to simultaneously determine differences in the means among treatments $(p<0.05$; GraphPad Software, Inc., Prism Ver. 6.0c).

\section{Results}

Tissue $\mathrm{C}, \mathrm{N}$ and $\mathrm{P}$ content

The belowground biomass used in the experiments had a C:N molar ratio of 42:1 and a N:P molar ratio of $65: 1$. This N:P ratio is similar to the N:P ratio for dead $S$. alterniflora roots and rhizomes from a Terrebonne estuary that had a $\mathrm{N}: \mathrm{P}$ ratio averaging $52.5: 1$ for 12 months, and 58.5:1 for May (Darby and Turner 2008b), which is the month when the samples for this experiment were collected.

Gas production

The decomposition of the belowground biomass was not evident for three of the six treatments (Fig. 3).

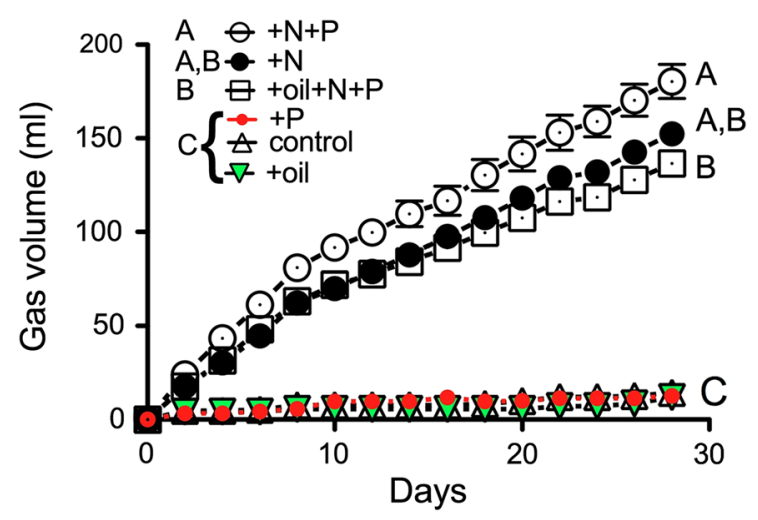

Fig. 3 Water displacement volumes for S. alternifora belowground biomass incubated with different additions to the artificial seawater medium, including no addition (control), nitrate, phosphate and oil. The values are the mean \pm 1 SE. The \pm 1 SE value is covered by the symbols in most cases. The letters indicate the groups with statistically significant different values on day 28 ( $p \leq 0.05)$, based on the results of a TukeyKramer post hoc test of differences $(p<0.05)$ 
There was virtually no gas production in the control chamber, in the chambers with added phosphorous, or in chambers with only oil added. Gas production in the $+\mathrm{N}$ chamber was strikingly evident, and the highest amount was observed in the +NP treatment chamber. Gas production in the chamber with $+\mathrm{NP}$ +oil was less than in the $+\mathrm{NP}$ treatment chamber.

The gas production after 28 days, from highest to lowest, was $+\mathrm{NP}=+\mathrm{N}>$ oil $+\mathrm{NP}>+$ oil; $+\mathrm{P}$; and no addition (control). We interpret these results to be that gas production was controlled almost exclusively by the addition of $\mathrm{N}$. A second interpretation is that the oil had no stimulatory effect on decomposition rates, and even a slightly inhibitory rate when combined with $+\mathrm{NP}$.

The gas collected from the chambers was flammable (blue flame) in all cases. We interpret this result as evidence for methane production, suggesting that the digestion chamber was anaerobic. The chamber with only +oil did not produce gas, and the chamber with +NP produced more gas than the chamber with +oil +NP.

\section{Oil degradation}

The average concentration of alkanes and aromatics at the end of the experiment for the +NP treatment chambers was 35 and $48 \%$, respectively of the amount in the control chambers with only oil added (Fig. 4), but the differences were not statisticallysignificant differences $(p=0.38$ and 0.11 , for the alkanes and aromatics, respectively). This suggests that the nutrient additions did not facilitate the microbial decomposition of the measured oil analytes.

\section{Discussion}

We successfully tested for differences in the potential effects of nutrient enrichment on the decomposition of belowground material in a laboratory setting. A positive attribute of this study is that it was able to assess the relative roles of $\mathrm{N}$ and $\mathrm{P}$ and oil on the decomposition of organic matter. The separate attention to three different additions/stressors allowed for the quantified comparison of each, including the possible synergistic interactions.

The results can be used to address the questions posed in the introduction: (1) the addition of oil to the
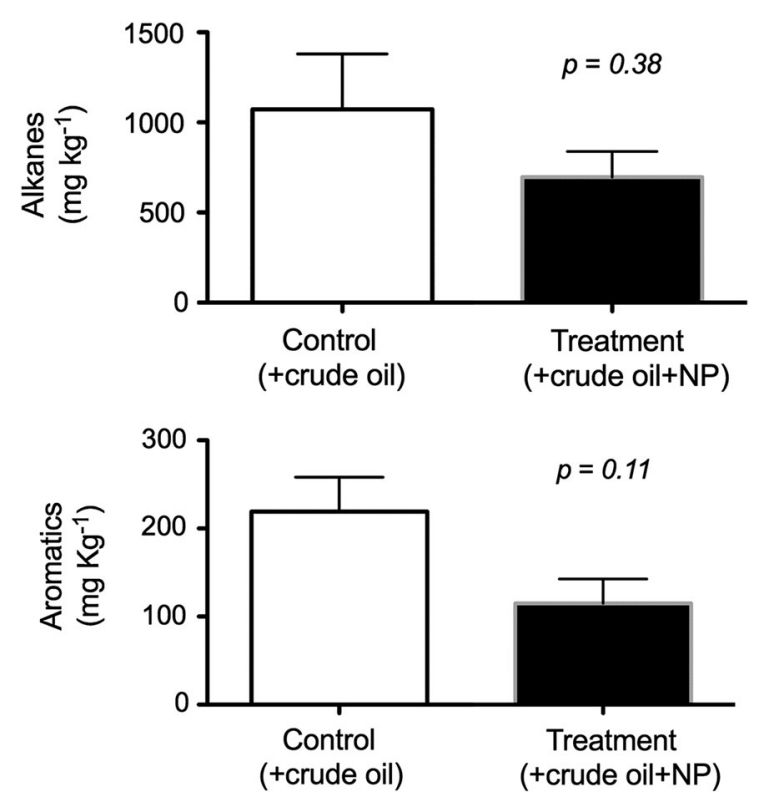

Fig. 4 The concentration of alkanes and aromatics in the control $(+$ crude oil $)$ and treatment $(+$ crude oil $+\mathrm{NP})$ chambers with belowground biomass

treatment chambers did not increase the decomposition rate in the absence of the added $\mathrm{N}$ and $\mathrm{P}$, and, decomposition rates in chambers with oil may have been depressed when nutrients, especially $\mathrm{N}$, were abundant. (2) the availability of N, not P, appeared to control the decomposition of the substrate under these conditions, and (3) there was no measurable synergism of $\mathrm{N}$ and $\mathrm{P}$ together on the decomposition rate.

The results described herein are consistent with the few examples from multi-year field studies in coastal systems mentioned in the introduction (e.g., Valiela et al. 1976; Morris and Bradley 1999; Turner 2011; Deegan et al. 2012). These results are also compatible with the analysis of data collected on the effects of $+\mathrm{NP}$ amendments over 7 years on soil organic matter in a tundra setting (Mack et al. 2004). The nutrient amendments there also resulted in less root biomass and a higher percent of the total root biomass in the surface layer. Carbon decomposition was stimulated more than aboveground carbon production, leading to a net change in carbon storage. Bragazza et al. (2006) and Larmola et al. (2013) also observed higher $\mathrm{CO}_{2}$ losses with nutrient amendments in Arctic tundra peats. Eggelsmann (1976) and Franzen (2006) inferred similar conclusions for peat systems in Europe, as did Harris et al. (1962) for peaty wetlands reclaimed for agriculture. 
A decomposition experiment specific to oil pollution was made by Mendelssohn and Sloccum (2004). They used cellulose (as cotton strips) as a surrogate for belowground organics in a field experiment on the effects of an oil spill in a Delaware (USA) salt marsh and concluded that oiling had no significant effect on cellulose decomposition rates. Delaune et al. (1979) conducted a laboratory study of the effects of oil on salt marsh soil decomposition and found no stimulatory effects (of oil) on methane production rates. These two results also agree with the results described herein.

These experiments are mostly about the decomposition of dead belowground biomass, which forms the vast majority of the organics in the soil profile of Louisiana salt marshes (Darby and Turner 2008a, b). There were no live roots or rhizomes in these experiments, and so the results should not be overapplied within the context of the entire belowground ecosystem, because we must consider the relative role of plant exudates on carbon turnover.

The variable effects of $+\mathrm{N},+\mathrm{P}$ and $+\mathrm{NP}$ on decomposition in these laboratory experiments match up quite well with the results from field studies examining the effects of nutrient amendments on carbon dioxide or oxygen exchange fluxes. Gas exchange did not increase with $+\mathrm{P}$ amendments at the minerogenic Goat Island salt marshes (South Carolina, USA), did increase with $+\mathrm{N}$ amendments, and increased the most with +NP (Wigand et al. 2015). Anisfeld and Hill (2012) described the results of an experiment in a Connecticut salt marsh with no effect of $+\mathrm{P}$ on gas exchange, and higher $\mathrm{CO}_{2}$ flux with $+\mathrm{N}$ and $+\mathrm{NP}$, which were similar. A similar experimental amendment scheme in Narragansett Bay (Rhode Island, USA), however, had no effect of the $+\mathrm{N}$ amendment, an intermediate effect with $+\mathrm{P}$ and a synergistic effect with +NP (Caffrey et al. 2007).

The context of these results for organic soils, at least in Louisiana, is that $\mathrm{P}$ additions have no apparent effects on decomposition, but that an increased P load to the marsh results in less root biomass (Darby and Turner 2008b) and lower soil strength (Turner 2011). This suggests that simultaneously increasing $\mathrm{N}$ and $\mathrm{P}$ loading to salt marshes, e.g., with cultural eutrophication, has no positive effects on marsh stability, and creates a potential negative outcome if buoyancy or storm surge exceeds the soil strength necessary to keep it from separating in the vertical direction. It seems possible that the roots and rhizome biomass would increase if the $\mathrm{P}$ loading was reversed, but this needs to be examined at the field level to verify. Nutrients in the coastal zone, of course, do not load separately from each other, nor will their reduction be done in isolation of each other.

The accumulation rate of organic matter in many salt marshes determines whether or not there is enough material to match present-day sea level rise (Turner et al. 2000). When nutrients weaken soils by way of decreasing organic accumulation or soil strength, then the soils may also subside and undergo longer flooding events. There is, therefore, a consequence to the salt marsh in both the vertical and horizontal dimension. This was seen in the aftermath of the 2010 DWH oil disaster (Fig. 1).

We conclude that oil may be toxic to the plant above some threshold value, and oil residues may not decay faster with nutrient additions. There is no direct cause-and-effect relationship between $+\mathrm{N}$ addition and marsh conservation, but there are negative indirect impacts on the soil. Thus the well-intentioned application of fertilizer to oiled marshes may, therefore, have significant and undesirable consequences.

Acknowledgments The experimental set-up was proposed and established by JEB, the experiment designed by JEB and RET, the laboratory data collected by JEB, and the initial data analysis and first draft of the ms. completed by RET. D. Daigle and L. Hollis kindly made suggestions on the draft manuscript. This research was made possible by a grant from the Gulf of Mexico Research Institute to the Coastal Waters Consortium that is administered by the Louisiana Universities Marine Consortium (LUMCON). The financial sources had no role in the design or execution of the study, data analysis, decision to publish, or manuscript preparation.

Open Access This article is distributed under the terms of the Creative Commons Attribution 4.0 International License (http:// creativecommons.org/licenses/by/4.0/), which permits unrestricted use, distribution, and reproduction in any medium, provided you give appropriate credit to the original author(s) and the source, provide a link to the Creative Commons license, and indicate if changes were made.

\section{References}

Anisfeld SC, Hill TD (2012) Fertilization effects on elevation change and belowground carbon balance in a Long Island Sound tidal marsh. Estuar Coasts 35:201-211

Benotti MJ, Abbene M, Terracciano SA (2007) Nitrogen loading in Jamaica Bay, Long Island, New York: predevelopment to 2005. United States Geological Survey, Scientific 
Investigations Report 2007-5051. Washington, DC Available on line only@ @ttp://pubs.usgs.gov/sir/2007/5051/ SIR2007-5051.pdf

Bragazza L, Freeman C, Jones T et al (2006) Atmospheric nitrogen deposition promotes carbon loss from peat bogs. Proc Nat Acad Sci (USA) 103:19386-19389

Caffrey JM, Murrell MC, Wigand C, McKinney R (2007) Effect of nutrient loading on biogeochemical and microbial processes in a New England salt marsh. Biogeochemistry 82:251-264

Darby FA, Turner RE (2008a) Below- and aboveground Spartina alterniflora production in a Louisiana salt marsh. Estuar Coasts 31:223-231

Darby FA, Turner RE (2008b) Below- and aboveground biomass of Spartina alterniflora: response to nutrient addition in a Louisiana salt marsh. Estuar Coasts 31:326-334

Debusk WF, Reddy KR (2005) Litter decomposition and nutrient dynamics in a phosphorus enriched everglades marsh. Biogeochemistry 75:217-240

Deegan LA et al (2007) Susceptibility of salt marshes to nutrient enrichment and predator removal. Ecol Appl 17(5):S42S63

Deegan LA, Johnson DS, Warren RS et al (2012) Coastal eutrophication as a driver of salt marsh loss. Nature 490:388-392

Delaune RD, Partrick WJ Jr, Buresh RJ (1979) Effects of crude oil on a Louisiana Spartina alterniflora salt marsh. Environ Pollut 20:21-31

Eggelsmann R (1976) Peat consumption under influence of climate, soil condition, and utilization. In: Proceedings international peat congress, vol 1, International Peat Society Poznan, pp 233-247

Franzen LG (2006) Increased decomposition of subsurface peat in Swedish raised bogs: are temperate peatlands still net sinks of carbon? Mires Peat 3:1-16

Hampson GR (2000) Destruction and recovery of the Winsor Cover, Cataumet, MA salt marsh from a \#2 fuel oil spill: a 25 year history. Environ Cape Cod 3:32-39

Harris CI, Erickson HT, Ellis NK, Larson JE (1962) Water-level control in organic soil, as related to subsidence rate, crop yield, and response to nitrogen. Soil Sci 94:158-161

Kearney MS, Riter CA, Turner RE (2011) Freshwater diversions for marsh restoration in Louisiana: 26 years of changing vegetative cover and marsh area. Geophys Res Lett 38:L16405. doi:10.1029/2011GL047847

Larmola T, Bubier JL, Kobyljanec C et al (2013) Vegetation feedbacks of nutrient addition lead to a weaker carbon sink in an ombrotrophic bog. Glob Change Biol. doi:10.1111/gcb12328

Lin QS, Mendelssohn IA, Suidan MT et al (2002) The doseresponse relationship between No. 2 fuel oil and the growth of the salt marsh grass, Spartina alterniflora. Mar Pollut Bull 44:897-902

Mack MC, Schuur EAG, Bret-Harte MS et al (2004) Ecosystem carbon storage in arctic tundra reduced by long-term nutrient fertilization. Nature 431:440-443

McClenachan G, Turner RE, Tweel AW (2013) Effects of oil on the rate and trajectory of Louisiana marsh shoreline erosion. Environ Res Lett 8:044030

Mendelssohn IA, Slocum MG (2004) Relationship between soil cellulose decomposition and oil contamination after an oil spill at Swanson Creek, Maryland. Mar Pollut Bull 48:359-370
Michel J, Owens EH, Zengel S et al (2013) Extent and degree of shoreline oiling: deepwater Horizon oil spill, Gulf of Mexico, USA. PlosOne 8:e65087

Milan CS, Swenson EM, Turner RE, Lee JM (1995) Accumulation rates estimated from 137Cs activity: variability in Louisiana salt marshes. J Coast Res 11:296-307

Morris JM, Bradley P (1999) Effects of nutrient loading on the carbon balance of coastal wetland environments. Limnol Oceanogr 44:699-702

Qualls RG, Richardson CJ (2008) Decomposition of litter and peat in the everglades: the influence of $\mathrm{P}$ concentrations. everglades experiments: lessons for ecosystem restoration. Ecol Stud 201:441-459 (Springer ebooks)

Silliman BR, Grosholz E, Bertness MD (eds) (2009) Human impacts on salt marsh ecosystems: Causes, consequences and solutions. University of California Press, Davis

Swarzenski CM, Doyle TW, Fry B, Hargis TG (2008) Biogeochemical response of organic-rich freshwater marshes in the Louisiana delta plain to chronic river water influx. Biogeochemistry 90:49-63

Turner RE (2011) Beneath the wetland canopy: loss of soil marsh strength with increasing nutrient load. Estuar Coasts 33:1084-1093

Turner RE, Swenson EM, Milan CS (2000) Organic and inorganic contributions to vertical accretion in salt marsh sediments. In: Weinstein M, Kreeger DA (eds) Concepts and controversies in tidal marsh ecology. Kluwer Academic Publishing, Dordrecht, pp 583-595

Turner RE, Howes BL, Teal JM et al (2009) Salt marshes and eutrophication: an unsustainable outcome. Limnol Oceanogr 54:1634-1642

Turner RE, Overton EB, Ashton BM et al (2014) Distribution and recovery trajectory of Macondo (Mississippi Canyon 252) oil in Louisiana salt marshes. Mar Pollut Bull 87:57-67

Valiela I, Teal JM, Persson NY (1976) Production and dynamics of experimentally enriched salt marsh vegetation: belowground biomass. Limnol Oceanogr 21:245-252

Venosa AD, Lee L, Suidan MT et al (2002) Bioremediation and biorestoration of a crude oil-contaminated freshwater wetland on the St. Lawrence River Bioremed J 6:261-281

Watson EB, Oczkowski AJ, Wigand C et al (2014) Nutrient enrichment and precipitation changes do not enhance resiliency of salt marshes to sea level rise in the Northeastern U.S. Clim Change 125:501-509

Wigand C, Brennan P, Stolt M et al (2009) Soil respiration rates in coastal marshes subject to increasing watershed nitrogen loads in southern New England, USA. Wetlands 29:952-963

Wigand C, Roman CT, Davey E et al (2014) Below the disappearing marshes of an urban estuary: historic nitrogen trends and soil structure. Ecol Appl 24:633-649

Wigand C, Davey E, Johnson R et al (2015) Nutrient effects on belowground organic matter in a minerogenic salt marsh, North Inlet, SC. Estuar Coasts. doi:10.1007/s12237-0149937-8 